\title{
A Oratória Parlamentar na primeira República (*)
}

\author{
MARIA VIDO
}

\section{Monografia}

N este país de oradores, a eloqüência, na primeira República, teve muita fôrça e prestígio, o que era de se esperar, devido não só aos inúmeros discursos, proferidos naquela época, como também às notáveis qualidades de alguns oradores parlamentares que, com um novo estilo, abrilhantaram êcse periodo de grandes transformações para a nossa História.

Pelo acima exposto, é que a matéria a ser tratada se torna difícil. Já o Embaixador João Neves da Fontoura, em sua belissima aula, referiu-se a esta mesma dificuldade:

"A mim me distribuíram uma das partes mais difíceis na série de preleções, tão magnificamente feitas por alguns dos nossos mais eminentes confrades.

"Difícil, porque foi provàvelmente na primeira República que mais se discursou neste país tão amigo da oratória etc...» (1)

Antes de mais nada, achamos imprescindivel frisar que a oratória da primeira República sófreu a influência espiritual do romantismo politico, porque, de um modo geral, com exceção do grupo simpatizante de Augusto Comte, em quase todos predominava o ideal de uma democracia formal e libertária. Em outras palavras, poderiamos dizer: Que a oratótia romântica foi a caracteristica marcante da oratória da primeira República.

Com referência aos oradores parlamentares da primeira República, citaremos, primeiramente, aquêles que mais se destacaram em todo o Brasil (aludiremos à eloqüência dos oradores falecidos), para em seguida, fazermos, em sintese, um estudo sôbre as principais características de Francisco Sá e Rui Barbosa. Teremos assim:

No Ceará, Francisco Sá, "o rouxinol de Diamantina", embora mineiro, representava o Ceará e não a sua terra natal; na Paraiba, Epitácio Pessoa, "a patativa do Norte"; na Bahia, Manoel Vitorino e Rui Barbosa, "a Águia

(*) O presente trabalho recebeu menção honrosa da Academia Brasileira de Letras (Prêmio Alcântara Machado).

(1) Item $2-1^{\circ}$ e $2^{\circ}$ parágrafos (da aula proferida no Curso de Oratória da Academia Brasileira de Letras, sôbre a Oratória parlamentar na primeira República). 
de Haia"; em Minas, David Campista, Calógeras, João Luís Alves, Afrânio de Mello Franco, Gastão da Cunha e Sabiro Barroso, "o canário do Cerro"; em São Paulo, Campos Salles, Álvaro de Carvalho, Prudente de Morais, Glicério, Bernardino de Campos, Júlio Prestes, Alfredo Ellis, César Bierrenback, Alfredo Pujol, João Monteiro, Antônio Covelo, Carlos de Campos e Brasilio Machado.

Francisco SÁ, "o rouxinol de Diamantina», possuía a eloqüência da palavra e a da frase. Calógeras dizia: "Quando orava Francisco Sá, sua voz era como um leque: ao abrir-se, tinha tôdas as côres e matizes." Sôbre um discurso seu, de oposição ao govêrno honrado e progressista de Afonso Pena, externou Rui a opinião, na presença de José Marcelino, e no testemunho de João Mangabeira, de que foi o mais belo que até então ouvira no Senado.

Não possuia Francisco Sá a cultura prodigiosa de Rui. Mas era homem de notável saber. Um tipo de Homem de Estado. Versado nos clássicos latinos e portuguêses, fraseava com elegância e apuro. Os seus discursos hão de ser, pois, relidos com encantamento e proveito.

O amor ao Brasil o fêz político. Deputado geral, mandatário da província do Ceará na última sessão legislativa da monarquia, o verbo altissonante de Francisco Sá selou em quinze de novembro o Parlamento Imperial. Não encontrou eco a sua exclamação, tentando estimular os hesitantes que começaram a abandonar o recinto: "Ainda somos os representantes da Nação." A República já estava proclamada e a sala se esvaziou num passe de mágica.

Triunfal é o seu retôrno ao Parlamento Republicano como representante do Ceará. Amigo de Glicério, que conhecera em Campinas, quando engenheiro ferroviário da Companhia Mogiana, alcança ruidoso sucesso na tribuna, discutindo os acontecimentos de 5 de novembro de 1897. Recebe ensurdecedora ovạção, ao fazer o elogio do Marechal Bittencourt. "Assim como o seu corpo se interpôs entre o Chefe da Nação e o punhal do sicário, formemos trdos um corpo só, interposto como antemural inexpugnável entre o crime e a lei, entre a anarquia e a ordem, entre os partidos e a Pátria", foram as últimas palavras do orador.

Revelou-se um tribuno para as massas. $\mathrm{O}$ artista da fina sensibilidade, o heleno que convivia com as musas, surgiu, todavia, ao traçar o necrológio do companheiro de bancada, José Avelino Gurgel do Amaral. Foi grande a repercussão dêsse discurso, que transformou o Parlamento em Academia. Não houve voz discrepante: o Brasil orgulhava-se do seu mandatário.

Os Anais parlamentares demonstram que profícua foi a sua atividade intelectual. Elaborou notáveis pareceres, repletos de dados estatísticos e de doutrina, como relator dos Orçamentos da Viação e Receita, na Comissão de Finanças, e os defendeu em plenário com o maior realce. Em assuntos de vias férreas, reconheciam-no os seus pares um competidor, em saber técnico, de Sampaio Correia e Paulo de Frontin. Economista, sempre o seu cৎpirito agasalhava as palavras de Gladstone a Jules Ferry: "Velai pelas finanças; é por elas que as democracias podem aparecer." 
O momento culminante da vida de Francisco Sá, como orador parlamentar, foi por ocasião em que se reunia a convenção para a escolha do c:andidato à Presidência da República - os concorrentes eram Rui Barbosa e Epitácio Pessoa Álvaro de Carvalho liderava os partidários de Epitácio. e Francisco Sá os correligionários de Rui. Presidia a sessão Antônio Azeredo. As galerias estavam repletas e o entusiasmo era indescritivel. Francisco Sá profere a oração que empolga a Assembléia. Raras vêzes subiu tão alto a eloqüência no Brasil.

Com o pincel de um Velázquez, pintou a trajetória da vida de Rui. Psicólogo, descreveu o momento político brasileiro. Em têrmos patéticos, fr'reteou a conduta dos convencionais. Homem de elite, Francisco Sá viveu com êsse discurso o instante da glória.

Rui Barbosa, "a Águia de Haia", foi prodígio de erudição, gênio verbal - insuperávêl na eloqüência da frase -. As melhores orações que legou à nossa literatura, êle as pronunciou quando ferido no seu orgulho, negado na sua glória, comc as respostas esmagadoras a César Zama e a Ramiro Barcelos.

Rui mais de uma vez, arrastado pela paixão partidária, provoca ódios e prevenções. Lauro Müller, que sempre o combateu, um dos seus infernados, ñ̂́o merecia tão rigoroso suplício, desenhado, como o foi, por uma pena embebida de fel. Batista Pereira entende que nesse retrato Rui sobrepujou a Saint-Simon, ao descrever o Cardeal Dubois. As memórias de Saint-Simon, rublicadas quase dois séculos depois de escritas, ainda provocam protestos dos descendentes dos retratados. O mesmo tem acontecido e há de suceder com os perfilados de Rui, quando se irritava com os políticos que negavam o seu gênio ou fingiam desconhecer os seus serviços à Pátria, da qual fôra constante apaixonado.

Não estudava por desfastio de espírito, ou por diletantismo: estudava com determinados objetivos e fins imediatos, em regra. Eis uma verdade que pode ser confirmada através de suas obras: "O Papa e o Concilio", "Cartas de Inglaterra" e "Réplica" - êsse monumento de lingüística e de dialética, obra que José Maria Belo apontou como a maior manifestação do gênio de Rui Barbosa.

A maior prova de que estudava com determinados objetivos e fins imediatos está no seguinte fato:

Rui, ao aceitar o convite para delegado à Conferência de Haia, adquiriu vasto arsenal de tratados de Direito Internacional, que assimilados e depurados pela sua incomparável inteligência, lhe permitiram enfrentar com galhardia os Martens, os Brown Scott, os Bourgeois e os Marshall. Foi dessa época em diante que mereceu a justa cognominação de "Águia de Haia".

Entre as diversas características de Rui, realmente, a de orador é uma das fundamentais. Na tribuna, êle se encontrava num dos ambientes mais próprios ao seu temperamento. Porque era uma das expressões mesmas da sua fôrça, que aí achava expansão ao exercício pleno de suas qualidades.

Antes de falar, como que já o estávamos a ouvir, tal como de Buffet disse Anatole France. É que Rui possuía no mais elevado grau o respeito e a admiração antecipada do auditório. 
Homero Pires, contemporâneo de Rui, referindo-se aos seus discursos, assim se expressou: "Mal começava a discursar, e a sua voz, sonora, extensa, volumosa, cheia de timbres, enchia todo o amplo recinto, repercutia nos ângulos mais distantes, e assim permanecia invariàvelmente até o fim, duas, três, quatro horas, sem uma interrupção, sem um descanso, sem carecer jamais de molhar a garganta, sem mesmo sequer tossir."

Com tais recursos, no parlamento brasileiro, nenhuma voz talvez sobrepuje a de Rui Barbosa, que, se mais comumente era o orador que tinha o gôsto dos atavios, sabia igualmente falar com simplicidade, tirando a sua fôrça às vêzes também da concisão, da correção, da severidade e sobretudo da lógica, que é na frase de Anatole France, o músculo do discurso.

Mas Rui não seria o grande orador que foi, se não fôsse um mestre consumado na arte de improvisação, a qualidade superior da eloqüência, como lhe chamou Emile Olivier. Elle improvisava integralmente, como quando repeliu com vigor e superioridade a interrupção provocadora do Sr. Ramiro Barcelos. E também improvisava à maneira de Lamartine: estudava o assunto, ordenava os argumentos, esboçava o plano e, ao contrário do que fazia o orador francês, desajudado de quaisquer notas consignadas no papel, entregue somente à memótia, deixava tudo o mais à inspiração do momento, ao seu extraordinário e magnífico poder verbal, ao seu domínio absoluto da palavra.

Rui foi também escritor torrencial, jornalista ilustre, advogado incomparável, campeão da justiça e da liberdade. Mas, acima de tudo, homem de ação, político na verdadeira acepção da palavra. Tanto isso era verdade que não gostava de ser chamado de bibliófilo, e de todos é conhecida a sua amargura pela denominação de "Jubileu Literário", dada pelos seus pseudoadmiradores aos cinqüenta anos de vida pública, em prol do direito, da justiça e da liberdade. "Jubileu Cívico" foi o que reclamou dos contemporâneos e é o que lhè dá a posteridade. 